\title{
EXAMINE WEBSITE QUALITY ON M-BANKING SERVICES ADOPTION IN BANGLADESH
}

\author{
Mohammad Abdullah Mahfuz ${ }^{1}$, Liza Khanam ${ }^{2}$ and Wang $\mathrm{Hu}^{3}$ \\ School of Management \\ Wuhan University of Technology \\ Wuhan, P.R.China, 430070.
}

\begin{abstract}
Mobile banking allows consumers to operate their banking activities through their mobile device, tab, notepad, etc. Now a day's m-banking service is considered one of the easiest and convenient ways for any kind of financial transaction. More ever, in the Bangladesh popularity of $m$-banking service increased day by day. But very few research conducted user acceptance of m-banking service in Bangladesh, especially the impact of web side quality on customer acceptance preference. For that reason, we proposed the extended unified theory of acceptance and use of technology(UTAUT2) model with the website quality to examine the influences of m-banking services adoption in Bangladesh. In this study data have been collected by questionnaire survey and the respondents were the m-banking users.This paper analyzed by applying partial least squares (PLS) based on 115 samples to test the conceptual model propose. Again, to determine the path significant levelthe bootstrapping method used with 300 resamples. The study found that social influence; facilitating conditions were the most significant antecedents of behavior intention and usage behavior. However, the results also confirm that website quality has no significant influence of the adoption of the m-banking services and the findings of this paper helps Bangladeshi Governments and private banks take proper initiative to emphasis on this specific areas to motivate the Bangladeshi customers to adopt more m-banking services.
\end{abstract}

\section{KEYWORD}

Website quality, m-banking, UTAUT2, PLS and Bangladesh.

\section{INTRODUCTION}

Last few decades financial firms have invested a significant amount of money in IT to get the competitive position in the market. It happens due to the proliferation of the wireless technologies as well as to increase the total number of cell phone users. Since consumers are using more and more mobile devices with internet facilities, therefore they become interested to do perform their banking activities through it. To cope with the consumers demand financial firms are now offering more mobile banking services than internet banking, Actually, mobile banking and internet banking are performing the same activities both are e-banking or online banking [1] but [2] the package of service facilities provided by the bank are different. In the case of [3] mobile banking consumers mainly use mobile device while in internet banking they are connected to internet through personal computer. That's why mobile banking has been developing and offering more services [4] than before which enhances the consumers and financial firm's relationship[3]. All these things happen for the development of the Information and Communication Technology (ICT) and implemented the new IT by the service oriented firms specially financial organizations [5].A significant number of research gives clear ideas about Information technology (IT) adoption models [6-11] and a few number of models elucidate about 
final user perspectives [12, 13]. Mobile banking reduces clients operational cost [14] and more convenient banking to meet consumers' needs perfectly than earlier [15].

In Bangladesh the guidelines for Mobile Financial Services(MFS) was issued on 22 September 2011.The Popularity of m-banking has significantly increased in the last four years, though it has not accepted in Bangladesh. The rapid growth of mobile phone users and countrywide coverage of the mobile operator's network has made their delivery channel an important tool-of-the-trade for extending banking services to the unbanked/banked population, especially to expedite faster delivery of remittances across the country.Bangladesh Bank, the central bank of Bangladesh, following a Bank-led model, defines the Mobile financial Services as -"Mobile Financial Services (MFS) is an approach to offering financial and banking services via mobile wireless networks which enables for user to execute banking transactions. That is, any mobile account holder can make deposits, withdraw, and to send or receive funds from their mobile account. However, the central bank also specifies that these services are, often, enabled by the use of bank agents that allow mobile account holders to transact an independent agent location outside of bank branches"[16]. According to data provided by Bangladesh Telecommunication Regulatory Commission (BTRC), that the total number of mobile phone subscribers has reached 131.956 millionbythe end of January, 2016, (www.btrc.gov.bd). And among these The total number of internet subscribers has reached 56.167million by the end of January, $2016(42.56 \%$ people have internet connection on their mobile phone) means $24.09 \%$ mobile users, around 31.8 million (Bangladesh Bankwww.bb.org.bd) are registered under mobile banking services which means $75.7 \%$, around 100.156 million, people have not yet adopted mobile banking services. This provides a good indication of the low rate of mobile banking users compared with the total population who usages internet. Here, we attached a summary of mobile banking activities [17] in Table 1.

Table 1: Summary of Mobile Financial Service (MFS) in Bangladesh

\begin{tabular}{|c|l|c|c|c|}
\hline & \multicolumn{1}{|c|}{ Description } & $\begin{array}{c}\text { Amount (in } \\
\text { November, } \\
2015)\end{array}$ & $\begin{array}{c}\text { Amount (in } \\
\text { December, } \\
2015)\end{array}$ & $\begin{array}{c}\text { \% Change } \\
\text { (Novembe } \\
\text { r, 2015 to } \\
\text { December, } \\
2015)\end{array}$ \\
\hline 1 & No. of approved Banks & 28 & 28 & - \\
\hline 2 & No. of agents & 552,652 & 561,189 & $1.54 \%$ \\
\hline 3 & No. of registered clients in Lac & 312.02 & 318.45 & $2.06 \%$ \\
\hline 4 & No. of active accounts in Lac & 125.47 & 132.18 & $5.35 \%$ \\
\hline 5 & No. of total transaction & $110,918,422$ & $114,847,19$ & $3.54 \%$ \\
\hline 6 & Total transaction in taka(in crore BDT) & $14,915.59$ & $16,124.81$ & $8.11 \%$ \\
\hline 7 & No. of daily average transaction & $3,697,281$ & $3,828,240$ & $3.54 \%$ \\
\hline 8 & $\begin{array}{l}\text { Average daily transaction (in crore } \\
\text { BDT) }\end{array}$ & 497.19 & 537.49 & $8.11 \%$ \\
\hline 9 & Additional information & $\begin{array}{c}\text { Amount (in } \\
\text { crore BDT) }\end{array}$ & $\begin{array}{c}\text { Amount (in } \\
\text { crore BDT) }\end{array}$ & \\
\hline a. & Inward Remittance & 3.70 & 4.25 & $14.86 \%$ \\
\hline b. & Cash In transaction & $6,300.22$ & $6,829.92$ & $8.41 \%$ \\
\hline c. & Cash Out Transaction & $5,479.66$ & $5,931.10$ & $8.24 \%$ \\
\hline d. & P2P transaction & $2,579.55$ & $2,750.84$ & $6.64 \%$ \\
\hline e. & Salary Disbursement (B2P) & 140.91 & 154.15 & $9.4 \%$ \\
\hline f. & Utility Bill Payment (P2B) & 99.42 & 109.12 & $9.76 \%$ \\
\hline g. & Others & & & \\
\hline
\end{tabular}


Numerous studies have attempted to explain about the benefits of m-banking such as checking account balances, transferring funds between accounts, and accessing other banking products and services from anywhere, at any point of time [18]. The prior studies of web site literature, researchers [19-22] identifies the multiple dimensions such as information quality, system quality, security, user satisfaction, service quality and ease of use.Therefore, we try identifying the influence of website quality to adoption of m-banking adoption in Bangladesh.

Through this paper, we try to present the overview of the mobile banking aspects, mobile banking adoption with prior most acceptance models [12] UTAUT2. Again, the author of the UTAUT2 [12] model suggested that to study this model with different mobile technology, in different countres, and less technologically advanced country. This is another good indication of this research.Further,we include website quality to extend the UTAUT2 model and to know about the influences those on the adoption of m-banking especially for Bangladeshi consumer through the UTAUT2 model and using the PLS method.

\section{Literature REVIEW}

\subsection{About UTAUT2:}

Nowadays UTAUT2 [12] model is considered the most popular model to study the consumer acceptance and use of ICTs. It included seven constructs, among them four construct such as performance expectancy (PE), effort expectancy (EE), facilitating conditions (FC), and social influence (SI) from the UTAUT model [11] and other three constructs such as hedonic motivation, price value and habit to adopt UTAUT2 model in a particular consumer market. The UTAUT model was [11] developed after reviewing eight popular theories which are related to information system those are Theory of Reasoned Action (TRA),Technology Acceptance Model(TAM), The Motivational Model(MM), Theory of Planned Behavior (TPB), The Model of PC Utilization (MPCU),Innovation Diffusion Theory (IDT), The Social Cognitive Theory(SCT) and TAM-TPB [23-26]. The [11] UTAUT model has an excellent acceptance in consumer perspective as well as organization perspective, but it has some limitation found by [27].Though researchers used the UTAUT model in user perspectives,especially in mobile technology [28] as well as other technologies for individuals and organizations use [29]. Therefore [12] introduced the UTAUT2 model in 2012.The UTAUT2 [12]model presents a justification for the taking and applying of information and communication technologies (ICTs) by consumers. It constitutes an extension of the UTAUT [11] model designated as UTAUT2 [12], which was devised to give details the acceptance and use of ICT specifically by the consumer. Since the UTAUT model was originally devised in order to elucidate the issues that affect the acceptance and use of ICT by employees where UTAUT [11] was as an extension of the popular TAM [8, 9]. Hence, we use this UTAUT2 model to study on m-banking services adoption in Bangladeshi consumer perspective by extending the existing model.

\subsection{Mobile Banking:}

Mobile banking is an important element of online banking that comprises an alternative delivery channel for financial and non-financial services that offered by different institutions, [30]. The term m-banking represented in various forms such as m-banking [31] branchless banking[32], $\mathrm{m}$ payments, m-transfers, m-finance [33]. As a survey report 2015 of The Federal Reserve survey defines mobile banking as [34]"using a mobile phone to access your bank or credit union account. This can be done either by accessing your bank or credit union's web page through the web browser on your mobile phone, via text messaging, or by using an app downloaded to your mobile phone". M-banking transaction or accessibility of financial information is not popular or spread out through the mass people as expected though they offer more opportunities than before. 
International Journal of Computer Science \& Information Technology (IJCSIT) Vol 8, No 2, April 2016

Table 2: Summary of m-banking adoption based on the UTAUT, UTAUT+ and UTAUT2 model.

\begin{tabular}{|c|c|c|c|}
\hline Theory & Author(s) & $\begin{array}{l}\text { Countries and } \\
\text { sampling }^{1}\end{array}$ & $\begin{array}{c}\text { Findings } \\
\text { Significant direct relationships with ATT, INT and USE }{ }^{2}\end{array}$ \\
\hline UTAUT2 & [35] & $\begin{array}{l}\text { Mozambique } \\
(252)\end{array}$ & $\begin{array}{l}\mathrm{BI} \rightarrow \mathrm{UB}(0.121) ; \mathrm{PERE} \rightarrow \mathrm{INT}(0.362) ; \mathrm{EE} \rightarrow \mathrm{INT}(0.039) ; \\
\mathrm{SI} \rightarrow \mathrm{INT}(-0.022) ; \mathrm{FC} \rightarrow \mathrm{INT}(0.55) ; \mathrm{BI} \rightarrow \mathrm{USE}(0.121) \\
\mathrm{HM} \rightarrow \mathrm{BI}(.184) \mathrm{HT} \rightarrow \mathrm{BI}(.401) \mathrm{PV} \rightarrow \mathrm{BI}(.059) .\end{array}$ \\
\hline \multirow[t]{2}{*}{ UTAUT+ } & [36] & Nigeria (231) & $\begin{array}{l}\mathrm{BI} \rightarrow \mathrm{UB}(0.319) ; \mathrm{EE} \rightarrow \mathrm{INT}(0.1041) ; \mathrm{PD} \rightarrow \mathrm{INT}(0.138) ; \\
\mathrm{INT} \rightarrow \mathrm{USE}(0.307) .\end{array}$ \\
\hline & [37] & SA, Nigeria (451) & NA \\
\hline \multirow[t]{6}{*}{ UTAUT } & [5] & $\begin{array}{l}\text { Portugal } \\
\text { (194) }\end{array}$ & $\begin{array}{l}\mathrm{PERE} \rightarrow \mathrm{INT}(0.40) ; \mathrm{EE} \rightarrow \operatorname{INT}(0.10) ; \mathrm{SI} \rightarrow \mathrm{INT} 0.10) ; \\
\mathrm{FC} \rightarrow \text { INT }(0.18) ; \mathrm{BI} \rightarrow \operatorname{USE}(0.64)\end{array}$ \\
\hline & [28] & Taiwan (441) & $\begin{array}{l}\mathrm{PERE} \rightarrow \mathrm{INT}(0.318) ; \mathrm{EE} \rightarrow \mathrm{INT}(0.080) ; \mathrm{SI} \rightarrow \mathrm{INT} 0.721) ; \\
\mathrm{CRE} \rightarrow \mathrm{INT}(0.147) ; \mathrm{COS} \rightarrow \mathrm{INT}(0.352) ; \mathrm{FC} \rightarrow \mathrm{INT}(0.560) ; \\
\mathrm{SE} \rightarrow \mathrm{INT}(0.165)\end{array}$ \\
\hline & [38] & USA (223) & NA \\
\hline & [39] & Malaysia (184) & $\begin{array}{l}\text { PU } \rightarrow \text { INT }(0.439) ; \text { PEOU } \rightarrow \text { INT }(0.291) ; \text { CONV } \rightarrow \text { INT } \\
(0.051) ; \mathrm{SEC} \rightarrow \text { INT }(0.497)\end{array}$ \\
\hline & [40] & USA (122) & $\begin{array}{l}\text { PERE } \rightarrow \text { INT }(0.499) ; \text { TRU } \rightarrow \text { INT }(0.131) ; \text { RIS } \rightarrow \text { INT } \\
(0.231) ; \text { TRU } \rightarrow \text { INT }(0.177) ; \text { SE } \rightarrow \text { INT }(0.167) .\end{array}$ \\
\hline & [41] & China (250) & $\begin{array}{l}\mathrm{PE} \rightarrow \mathrm{USE}(0.37) ; \mathrm{SI} \rightarrow \mathrm{USE}(0.22) ; \mathrm{FC} \rightarrow \mathrm{USE}(0.24) ; \\
\mathrm{TTF} \rightarrow \mathrm{USE}(0.30)\end{array}$ \\
\hline
\end{tabular}

Notes: ${ }^{1}$ Total number of responses of the respective study (Sample size).

${ }^{2}$ ATT $=$ Attitude toward use/m-banking; INT= Intention and USE $=$ Usages.

$\mathrm{BI}=$ Behavioral Intention;PERE=Performance expectancy; $\mathrm{EF}=$ Effort expectancy;SI=Social influence $; \mathrm{FC}=$ Facilitation conditions; HB=Habit; HM=Hedonic Motivation; PV=Price Value;PD=Power Distance; USE=User Behavior; $\mathrm{CRE}=$ Credibility; $\quad \mathrm{COS}=\mathrm{Cost}$ SE=Self-efficacy;PU=Perceived Usefulness;PEOU=Perceived ease of use; $\mathrm{CONV}=$ Convenience; $\mathrm{SEC}=$ Security; RIS=Perceived risk; TRU=Trust; TTF=Task technology fit.

\subsection{Mobile Banking Adoption}

Researchers found significant interest in m-banking especially in practice and academia such as, [41-43].Some well-known accepted theories and models also studied in m-banking adoption such as technology acceptance model (TAM) [8], Innovation diffusion theory (IDT) [6], unified theory of acceptance and usage of technology (UTAUT) [7] have been used to study the adoption or the intention to adopt m-Banking. Some prior studies related to mobile banking in Bangladesh perspectives are given: [44] using the TAM model and [45] used TAM and DTPB model. Here the following table (Table 2) we summarized the mobile banking adoption related previous work based on the UTAUT2, UTAUT, UTAUT + related model.

To the best of our knowledge, none of the extant studies have taken a holistic view to assess $\mathrm{m}$ Banking adoption by examining the UTAUT2 model.One research had been done by using the UTAUT2 model for mobile banking services adoption with considering culture as a moderator variable[35] (Table 1) but no research in Bangladesh perspectives. This is our main strength to find out the influences of website quality on m-banking services Adoption in Bangladesh. We are applying the UTAUT2 model using PLS.

\subsection{Website Quality:}

A review of some of the research in this area follows, relating to banks' websites, portals or other service and product providers interested in e-business. According to [46] found that web attribute have significant influence on online behaviors.[47] Investigated the concept of service quality in e-banking portals and developed their service quality model. Researcher [19] developed an 
instrument that captures the key characteristics of website quality from the user's perspective. Resent study found that within 2017 the total number of customers of m-banking will exceed I billion, though it equal to only $15 \%$ of the global mobile subscriber holder. As indicated by the work of [48], website quality, with its dimensions of design structure and content, is an important factor for achieving customer satisfaction. Social influence is important for the community's satisfaction assessment, while system quality is important for search engine websites [49].The characteristics of website system include as system, information and service quality [50].

To the bestof our knowledge, one research had been done by using UTAUT2 model to mobile banking services adoption with considering culture as a moderator variable[35] (Table 1) but no research in Bangladesh perspectives. This is our main strength to find out the impact of website quality on m-banking services adoption in Bangladesh. We are applying the UTAUT2 model using PLS.

\subsection{Research Model and Hypothesis}

Based on the literature, we can propose a model (Figure- 1) along with their operational definition (Table-2) we hypothesize that are given below:

\subsubsection{The Research Model}

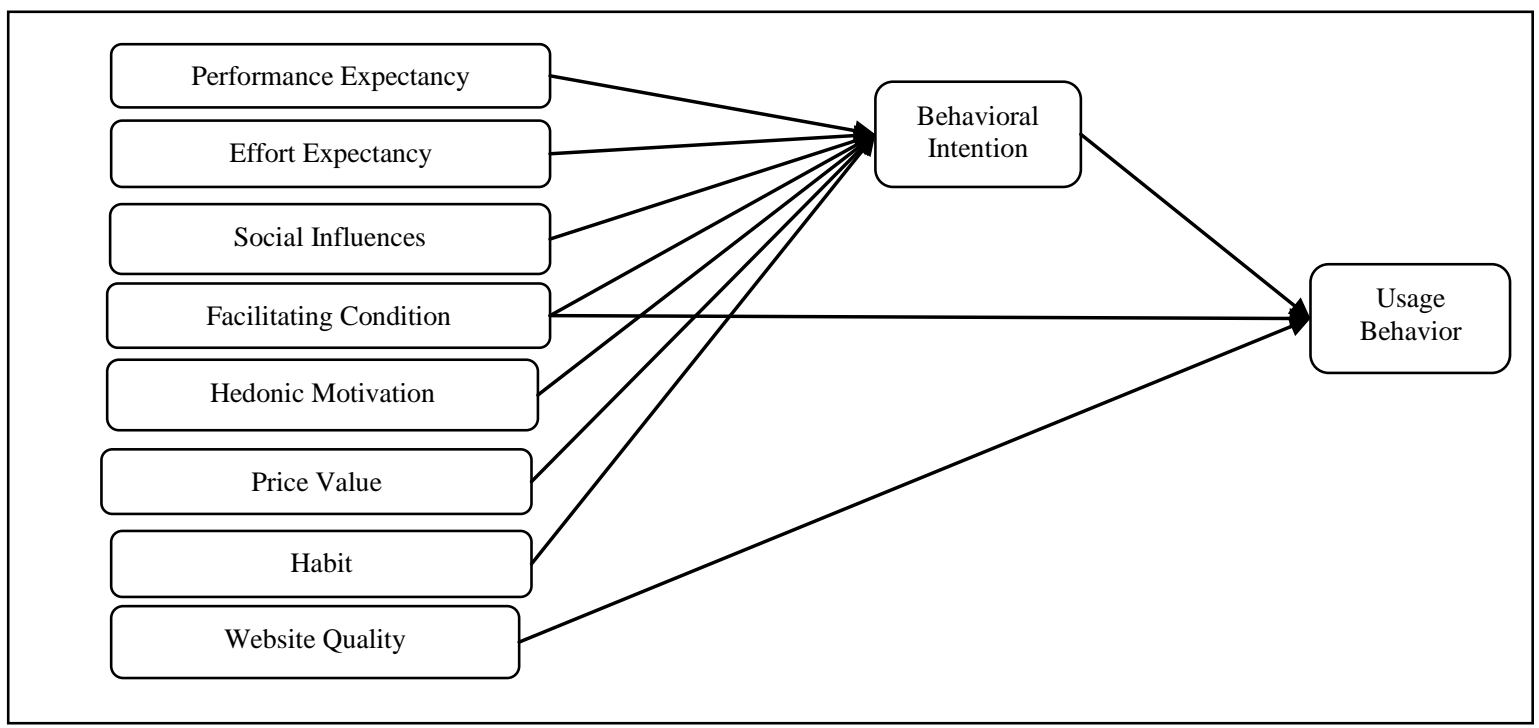

Figure: WQ-MBA-UTAUT2

\subsubsection{Operational Definitions:}

Table 3: Operational Definitions of Proposed model

\begin{tabular}{|c|l|c|}
\hline Constructs & \multicolumn{1}{|c|}{ Definition } & $\begin{array}{l}\text { Source } \\
\text { S }\end{array}$ \\
\hline $\begin{array}{c}\text { Performance } \\
\text { Expectancy }\end{array}$ & $\begin{array}{l}\text { "The degree to which using a technology will provide benefits to } \\
\text { consumers in performing certain activities". }\end{array}$ & {$[12]$} \\
\hline $\begin{array}{c}\text { Effort } \\
\text { Expectancy }\end{array}$ & $\begin{array}{l}\text { "The degree of ease/effort associated with consumers" use of the } \\
\text { technology". }\end{array}$ & {$[12]$} \\
\hline $\begin{array}{c}\text { Social } \\
\text { Influence }\end{array}$ & $\begin{array}{l}\text { "The consumers perceive that important others (e.g.family and friends) } \\
\text { believe that they should use a particular technology". }\end{array}$ & {$[12]$} \\
\hline
\end{tabular}


International Journal of Computer Science \& Information Technology (IJCSIT) Vol 8, No 2, April 2016

\begin{tabular}{|c|c|c|}
\hline $\begin{array}{l}\text { Facilitating } \\
\text { Conditions }\end{array}$ & $\begin{array}{l}\text { "Consumers' perceptions of the resources and support available to perform } \\
\text { a behavior. }\end{array}$ & {$[12]$} \\
\hline $\begin{array}{c}\text { Hedonic } \\
\text { Motivation }\end{array}$ & "The pleasure or enjoyment derived from using a technology" & {$[12]$} \\
\hline Price Value & $\begin{array}{l}\text { "Consumers' cognitive tradeoff between the perceived benefits of the } \\
\text { applications and the monetary cost of using them" }\end{array}$ & [51] \\
\hline Habit & $\begin{array}{l}\text { "The extent to which people tend to perform behaviors automatically } \\
\text { because of learning" }\end{array}$ & [52] \\
\hline $\begin{array}{l}\text { Website } \\
\text { Quality }\end{array}$ & "The performance of the system in delivering information" & [53] \\
\hline $\begin{array}{l}\text { Behavioral } \\
\text { Intention }\end{array}$ & The Strength on one's intention to use the technology in the future. & [54] \\
\hline
\end{tabular}

\subsubsection{Hypotheses of the Study}

\section{Performance Expectancy:}

Performance expectancy (PE) reflects user perception of performance improvement by using mobile banking on tasks, i.e., it is the degree to which an individual believes that using mobile banking will help to attain gains inperforming banking tasks [11]. It reflects user perception of performance improvement by using Internet banking, such as convenience of payment, fast response, and service effectiveness [41]. Researcher revealed that it will be positive consequences if consumers find any benefit from using computing technology[55].Since, author[40] found that it is one of the most important factors for accepting intention and also can improve the perception of mobile banking adoption[56] Therefore, we hypothesize:

H1.The influence of Performance Expectancy (PE Behavioral Intention (BI) will be
positive. Effort expectancy:

Effort expectancy construct represents the perceived ease of use (TAM) of an IS [57, 58];[5, 59, 60] and also has a positive influence on the behavioral intention. Some features such as user interfaces, content design, and functional ability; [11] of m-Banking can influence its adoption. The consumers will use more mobile banking services if they face fewer problems[61]. It also depends upon the ease of use to conduct m-banking transaction[62] Therefore, we hypothesize:

H2.The influence of Effort Expectancy (EF) on Behavioral Intention (BI) will be positive.

\section{Social influence:}

Social influence is a direct antecedent of behavioral intention.Scholar[11]defines social influence as the degree to which an individual perceives that it is important for others to believe that he or she uses the new technology or complies with others' expectations. It is the notion that individual behavior is influenced by the way peers or family members value the use of $\mathrm{m}$ Banking. The individual may feel trendy and professional by using a new service technology such as m-Banking. 
H3.The influence of Social Influence (SI), on Behavioral Intention (BI) will be positive. Facilitating conditions:

Facilitating conditions refer the facilities provided by the financial organization to use the mobile banking services whenever necessary like technical infrastructure[11]. It is same as perceived behavioral control of TPB. It helps the users to adopt the system. Because if someone registered for using mobile banking services he or she must require to know how to operate smart phones or devices along with internet connection, installed specific mobile applications, to handle the carriers and security as well. Therefore, the service providers should provide the relevant documents, demos, graphs to encourage the users to adopt new services. That's why, if user get any facility to know how to operate m-banking services. Therefore, we hypothesize:

H4. The Facilitating Conditions (FC) on Behavioral Intention (BI) will be positive. H5. The Facilitating Conditions (FC) on Usages Behavior (BI) will be positive.

\section{Hedonic motivation:}

A number of literature [63, 64], based on ICT found that hedonic motivation has an influence on behavioral intention and actual use of that technology. Researcher found that hedonic motivation is considered the most important factor and the acceptance will be greater to intention if consumers find more services from mobile services[4]. It has a positive relationship with the behavioral intention on mobile banking[35]. So, we hypothesize:

\section{H6.The influence of Hedonic Motivation (HM) on Behavioral Intention (BI) will be positive.}

\section{Price value:}

The second constructs introduce in UTAUT2 is price value. It has different meaning in UTAUT model and UTAUT2 model. According to[12], monetary cost will incur when consumer use any technology oriented services and that is related and influence on consumers buying situation. It is important to note that [12] included into the UTAUT2 the price value construct because it provide more economic benefits than its monetary costs to its users. Therefore, it will be positive and also associate with a monetary cost if consumers find more benefits of mobile banking services.The prior study[35]discuss the price value issue on mobile banking services. Therefore, we hypothesize:

\section{H7.The influence Price value (PV) on Behavioral Intention (BI) will be positive.}

\section{Habit:}

Before introducing the last and the third constructs habit in UTAUT2 model, a number of studies $[52,65,66]$. In UTAUT2 habit took from[52] which explained the use of technology has a direct effect on it and play as a moderate role on intention to use since the more habit turn the consume less conscious to use the technology. The present behavior is depends upon the prior behavior and frequency of behavior [67].In the prior study[35] found that habit strongly influence on behavior intention on mobile banking adoption. Therefore, we hypothesize: 
International Journal of Computer Science \& Information Technology (IJCSIT) Vol 8, No 2, April 2016

H8.The influence of Habit (HB) on Behavioral Intention (BI) will be positive.

\section{Website quality:}

Website quality refers the quality of the website as well as the products or services offered by the particular web system [50]. According to [68], web design element is considered as a primary driver of online behavior. The website also influences consumer's intention to buy when they are using company's websites through visiting. Therefore, it depends upon website quality and information quality.Website quality means the design, functions, security of the website and information quality means empathy, clarity and accuracy. Again, website quality affects on behavioral intention and usages intention in prior studies [69-74]. Therefore, we hypothesize:

H9. Website quality (WQ) will have a positive and significant influence on usage behavior to use m-banking services.

\section{Behavioral Intention:}

Individual behavior is influenced by the individual intention revealed by the prior psychological theories (Yu, 2012), which is supported by the UTAUT and UTAUT2 models and find significant influences on technology usages. Therefore, we hypothesize:

H10. Behavioral Intention (BI) will have a significant positive influence on Usage Behavior (UB) to use m-banking services.

Table 4: Measurement Scale

\begin{tabular}{|c|l|c|c|}
\hline Construct & & \multirow{2}{|c|}{ Measure scale } & Source \\
S
\end{tabular}


International Journal of Computer Science \& Information Technology (IJCSIT) Vol 8, No 2, April 2016

\begin{tabular}{|c|c|c|c|}
\hline \multirow[t]{4}{*}{ Habit } & The use of mobile banking has become a habit for me. & \multirow{4}{*}{$\begin{array}{l}\text { HT1 } \\
\text { HT2 } \\
\text { HT3 } \\
\text { HT4 }\end{array}$} & \multirow[t]{4}{*}{ [12] } \\
\hline & I am addicted to using mobile banking. & & \\
\hline & I must use mobile banking. & & \\
\hline & Using mobile banking has become natural to me. & & \\
\hline \multirow[t]{3}{*}{$\begin{array}{l}\text { Website } \\
\text { Quality }\end{array}$} & $\begin{array}{l}\text { M-banking websites appear safe and secure for carrying out } \\
\text { transactions. }\end{array}$ & \multirow{3}{*}{$\begin{array}{l}\text { WQ1 } \\
\text { WQ2 } \\
\text { WQ3 }\end{array}$} & \multirow[t]{3}{*}[75,76]{} \\
\hline & $\begin{array}{l}\text { m-banking websites look attractive and use fonts and colour } \\
\text { properly }\end{array}$ & & \\
\hline & M-banking websites look organized. & & \\
\hline \multirow{3}{*}{$\begin{array}{l}\text { Behavioral } \\
\text { Intention }\end{array}$} & I intend to use the system in the next months & BI & \multirow[t]{3}{*}{ [12] } \\
\hline & I predict I would use Mobile banking in the next months & $\mathbf{B 2}$ & \\
\hline & I plan to use the system in the next months & B3 & \\
\hline $\begin{array}{c}\text { Usages } \\
\text { Behavior }\end{array}$ & What is your actual frequency of use of Mobile banking services? & UB & [29] \\
\hline
\end{tabular}

\section{METHODOLOGY AND MEASUREMENT INSTRUMRNT}

A comprehensive set of questionnaire is being used in this research. The questionnaire design was divided into two sections. We prefer survey instruments with a 7 point Likert scale[77]. The first section is comprised of five questions which consist of demographic profile and two questions about the usages of internet and mobile banking. The second section consists of 35 questions of 10 constructs. The items and scales for the UTAUT2constructs were adapted from[11, 12] usage behavior from [29],website quality from [75, 76] to improve content validity[78].The participants were asked to scale the relevant facts on a Likert scale from 1 to 7 with a response continuum from "strongly disagree" to "strongly agree" (Table 4). Here, we prefer to collect data to whohas at least a mobile bank account in Bangladesh and authors prefer convenient sampling for this researchbecause it is cost effective[79]. Finally, we collect 115 valid data from customer to analyze.It should be noted that small sample is appropriate for Partial Least Squared (PLS)[80].Since [81] suggested that to test the structure equation model, researchers can collect data minimum 91 samples for maximum 10 of arrows pointing to the latent variable in the model. According to $[82,83]$ to analysis by PLS, it required the sample 10 times for the following possibilities: a) the largest number of indicator $b$ ) the depending variables that interacting through the independent variables. This study required 100 samples to make data analysis by PLS which is supported by the prior studies. For data analysis SmartPLS 2.0 were used [84].

\section{RESUlT AND ANALYSIS}

\subsection{Demographic and other Information:}

In this Study, total one hundred fifteen respondent data were analyzed. Among them male respondents and female respondents were respectively 78 and 37 . The ratio of male respondent is twice than female. Here, most of the respondents' age between 20-30 years and the most interesting things is the young generation whose age below 20 is 16.5 percent. Most of the respondents had a bachelor and master's degree. The researcher gives their opinion of mobile banking users are highly educated, young and wealthy person with good knowledge of using internet technology[85].Therefore they are knowledgeable to use the mobile banking. Many studies have revealed that demographic factors impacts of online banking [86-89]. Here, the respondents were asked about the experience of using information technology, which is also satisfactory and the most important matter is that they are using mobile banking mobile banking several times as well as occasionally. From the above Table 5, we can get a clear detailed idea of the nature of the respondents who are using mobile banking activities in Bangladesh. 
Table 5: Demographic and other Information

\begin{tabular}{|c|c|c|c|c|c|c|c|}
\hline & & $\begin{array}{c}\text { Frequenc } \\
\mathbf{y}\end{array}$ & $\begin{array}{c}\text { Valid } \\
\text { Percen } \\
t\end{array}$ & & & $\begin{array}{c}\text { Frequen } \\
\text { cy }\end{array}$ & $\begin{array}{c}\text { Valid } \\
\text { Percent }\end{array}$ \\
\hline \multirow{4}{*}{ Gender } & Male & 78 & 67.8 & \multirow{6}{*}{$\begin{array}{l}\text { Educational } \\
\text { background }\end{array}$} & Illiterate & 2 & 1.7 \\
\hline & Female & 37 & 32.2 & & Secondary & 30 & 26.1 \\
\hline & & & & & Bachelor & 43 & 37.4 \\
\hline & Total & 115 & 100.0 & & Masters & 36 & 31.3 \\
\hline \multirow{6}{*}{ Age } & $\begin{array}{l}\text { Less than } \\
20\end{array}$ & 19 & 16.5 & & Others & 4 & 3.5 \\
\hline & $20-30$ & 78 & 67.8 & & Total & 115 & 100.0 \\
\hline & $40-50$ & 15 & 13.0 & \multirow{7}{*}{ Occupation } & & & \\
\hline & $50-60$ & 3 & 2.6 & & Employed & 50 & 43.5 \\
\hline & & & & & $\begin{array}{c}\text { Unemploy } \\
\text { ed }\end{array}$ & 42 & 36.5 \\
\hline & Total & 115 & 100.0 & & Housewife & 9 & 7.8 \\
\hline \multirow{5}{*}{$\begin{array}{l}\text { Marital } \\
\text { status }\end{array}$} & Married & 40 & 34.8 & & Retired & 14 & 12.2 \\
\hline & Unmarried & 73 & 63.5 & & & & \\
\hline & Widowed & 1 & .9 & & Total & 115 & 100 \\
\hline & $\begin{array}{l}\text { Divorce/ } \\
\text { Separated }\end{array}$ & 1 & .9 & \multirow{6}{*}{$\begin{array}{l}\text { Experience } \\
\text { in using } \\
\text { information } \\
\text { technology }\end{array}$} & $\begin{array}{l}\text { Less than } \\
\text { one year }\end{array}$ & 15 & 13.0 \\
\hline & Total & 115 & 100.0 & & $1-3$ & 41 & 35.7 \\
\hline \multirow{5}{*}{$\begin{array}{c}\text { Frequency } \\
\text { of using } \\
\text { mobile } \\
\text { banking } \\
\text { services }\end{array}$} & Occasionall & 29 & 25.2 & & $1-4$ & 39 & 33.9 \\
\hline & $\mathrm{y}$ & & & & & & \\
\hline & $\begin{array}{c}\text { Several } \\
\text { times }\end{array}$ & 75 & 65.2 & & 7-9 & 18 & 15.7 \\
\hline & Hardly use & 11 & 9.6 & & $\begin{array}{c}\text { More than } \\
10 \text { years }\end{array}$ & 2 & 1.7 \\
\hline & Total & 115 & 100.0 & & Total & 115 & 100.0 \\
\hline
\end{tabular}

Expert researchers differentiate between measurement and structural models and explicitly take measurement error into account[90].Smart PLS 2.0M3[84] was the software used to analyze the relationships defined by our theoretical model. 
Table 6: Item loading

\begin{tabular}{|c|c|c|c|c|c|}
\hline Construct & Item & Loading & Construct & Item & Loading \\
\hline \multirow{4}{*}{ PE } & PE1 & 0.8292 & \multirow{3}{*}{ HM } & HM1 & 0.8523 \\
\hline & PE2 & 0.8012 & & HM2 & 0.8693 \\
\hline & PE3 & 0.8706 & & HM3 & 0.9378 \\
\hline & PE4 & 0.7157 & \multirow{3}{*}{ PV } & PV1 & 0.8731 \\
\hline \multirow{4}{*}{$\mathbf{E F}$} & EF1 & 0.9039 & & PV2 & 0.9746 \\
\hline & EF2 & 0.905 & & PV3 & 0.7784 \\
\hline & EF3 & 0.8878 & \multirow{4}{*}{ HB } & HB1 & 0.8355 \\
\hline & EF4 & 0.9087 & & HB2 & 0.8895 \\
\hline \multirow{4}{*}{ SI } & SI1 & 0.9225 & & HB3 & 0.7993 \\
\hline & SI2 & 0.9262 & & HB4 & 0.9064 \\
\hline & SI3 & 0.9108 & \multirow{3}{*}{ WQ } & WQ1 & 0.9048 \\
\hline & SI4 & 0.8971 & & WQ2 & 0.8869 \\
\hline \multirow{4}{*}{ FC } & FC1 & 0.921 & & WQ3 & 0.7598 \\
\hline & FC2 & 0.9127 & \multirow{3}{*}{ BI } & BI1 & 0.9549 \\
\hline & FC3 & 0.8193 & & BI2 & 0.9723 \\
\hline & FC4 & 0.823 & & BI3 & 0.9638 \\
\hline
\end{tabular}

\subsection{Analysis of the Measurement Model}

In our study, measurement model was tested by the internal reliability, convergent and discriminant validity [91] where internal reliability is determined by Cronbach's alpha (CA) and composite reliability (CR)and the acceptance level of the indicator is 0.70 [92].In this study the calculated value (Table 6) CA (range from 0.8118 to 0.9579) and CR (range from 0.8808 to 0.9727 ) is more than the standard value. Convergent validity is acceptable when constructs have an average variance extracted (AVE) of at least 0.50 [92] where in our study also support this because AVE values stands from 0.6499 to 0.9224 from Table 7.

Table: 7-Convergent Validity, Discriminant Validity \& Reliability and Square root of AVE (in bold on diagonal) and factor correlation coefficients

\begin{tabular}{|l|l|l|l|l|l|l|l|l|l|l|}
\hline & BI & EF & FC & HB & HM & PE & PV & SI & UB & WQ \\
\hline BI & $\mathbf{0 . 9 6}$ & & & & & & & & & \\
\hline EF & 0.37 & $\mathbf{0 . 9 0}$ & & & & & & & & \\
\hline FC & 0.20 & 0.44 & $\mathbf{0 . 8 7}$ & & & & & & & \\
\hline HB & 0.06 & 0.16 & 0.14 & $\mathbf{0 . 8 5}$ & & & & & & \\
\hline HM & -0.08 & -0.02 & 0.00 & -0.13 & $\mathbf{0 . 8 8}$ & & & & & \\
\hline PE & 0.42 & 0.58 & 0.39 & 0.11 & -0.00 & $\mathbf{0 . 8 0}$ & & & & \\
\hline PV & -0.12 & -0.01 & 0.11 & 0.06 & 0.41 & -0.08 & $\mathbf{0 . 8 7}$ & & & \\
\hline SI & 0.42 & 0.46 & 0.44 & 0.11 & 0.00 & 0.63 & 0.01 & $\mathbf{0 . 9 1}$ & & \\
\hline UB & 0.56 & 0.56 & 0.37 & -0.03 & -0.02 & 0.59 & -0.07 & 0.51 & $\mathbf{1}$ & \\
\hline WQ & -0.10 & 0.01 & 0.08 & 0.34 & 0.11 & -0.03 & 0.24 & -0.10 & -0.13 & $\mathbf{0 . 8 5}$ \\
\hline CA & $\mathbf{0 . 9 5}$ & $\mathbf{0 . 9 2}$ & $\mathbf{0 . 8 9}$ & $\mathbf{0 . 8 9}$ & $\mathbf{0 . 8 8}$ & $\mathbf{0 . 8 1}$ & $\mathbf{0 . 8 7}$ & $\mathbf{0 . 9 3}$ & & $\mathbf{0 . 8 1}$ \\
\hline CR & $\mathbf{0 . 9 7}$ & $\mathbf{0 . 9 4}$ & $\mathbf{0 . 9 2}$ & $\mathbf{0 . 9 1}$ & $\mathbf{0 . 9 1}$ & $\mathbf{0 . 8 8}$ & $\mathbf{0 . 9 1}$ & $\mathbf{0 . 9 5}$ & & $\mathbf{0 . 8 8}$ \\
\hline AVE & $\mathbf{0 . 9 2}$ & $\mathbf{0 . 8 1}$ & $\mathbf{0 . 7 5}$ & $\mathbf{0 . 7 3}$ & $\mathbf{0 . 7 8}$ & $\mathbf{0 . 6 4}$ & $\mathbf{0 . 7 7}$ & $\mathbf{0 . 8 3}$ & & $\mathbf{0 . 7 2}$ \\
\hline
\end{tabular}

Note: PE: performance expectancy; EF: effort expectancy; SI: social influence; FC: Facilitating conditions; HM: hedonic motivation; PV: price value; HB: Habit;WQ: Website Quality BI: behavioral intention; UB: use behavior.CA: Cronbach's alpha and CR: composite reliability; and (AVE) average variance extracted. 


\subsection{Analysis of the Structural Model}

The structural model was developed to identify the relationships among the constructs in the research model. The Bootstrap method was used to test the hypothesis[93]. In our study, tested the relationship between dependent and independent variables by path coefficient ( $\beta$ )[94] mentioned path coefficients with standardized values above 0.20 are usually significant and those with values below 0.10 are usually not significant.

Table 8: Summary of Results

\begin{tabular}{|c|l|c|c|c|c|}
\hline Hypothesis & Path & Coefficient & t Statistics & P value & Comments \\
\hline H10 & BI -> UB & 0.5012 & 4.8398 & $0.000^{* * * *}$ & Supported \\
\hline H2 & EF -> BI & 0.1762 & 1.3506 & 0.1796 & Not Supported \\
\hline H4 & FC -> BI & -0.0488 & 0.5527 & 0.5815 & Not Supported \\
\hline H5 & FC -> UB & 0.2806 & 2.6256 & $0.0098^{* * * *}$ & Supported \\
\hline H8 & HB -> BI & -0.0054 & 0.0474 & 0.9622 & Not Supported \\
\hline H6 & HM - BI & -0.045 & 0.3706 & 0.7116 & Not Supported \\
\hline H1 & PE -> BI & 0.1704 & 1.092 & 0.2771 & Not Supported \\
\hline H7 & PV -> BI & -0.0859 & 0.6803 & 0.4976 & Not Supported \\
\hline H3 & SI -> BI & 0.2579 & 2.1819 & $0.0311^{* * *}$ & Supported \\
\hline H9 & WQ -> UB & -0.1042 & 1.1192 & 0.2653 & Not Supported \\
\hline
\end{tabular}

$$
* \mathrm{p}=0.05 * * \mathrm{p}=0.01 * * * \mathrm{p}=0.001
$$

\section{$R^{2}$ for Behavior Intention $(B I)=.253, R^{2}$ Usages Behavior $(U B)=.403$}

The model explains $25.3 \%$ of the variance in intention to use m-banking $(0.253)$ and $40.3 \%$ of variance in actual use of m-banking (0.403).

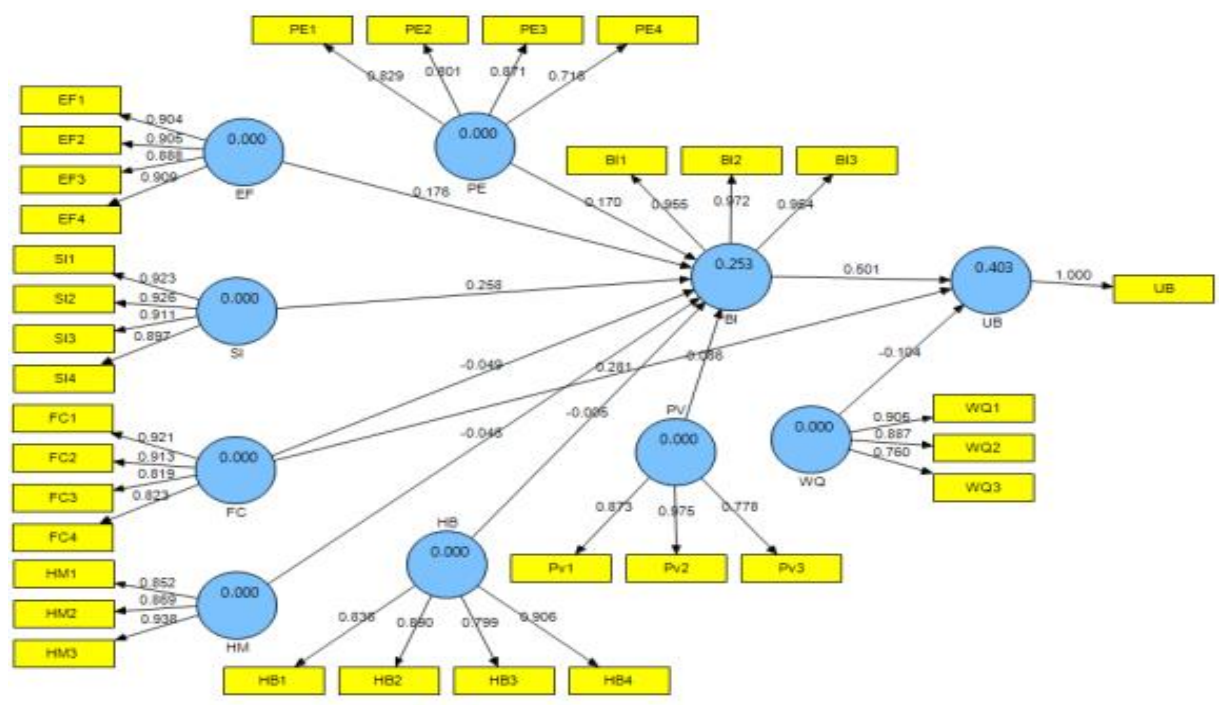

Figure 2. Path Model of the Mobile banking adoption.

\section{DISCUSSION AND FINDINGS}

In this study, to explain the model, the author uses different forms of significant level these are $\mathrm{p}<$ $0.01(\mathrm{t}>1.645) ; \mathrm{p}<0.05(\mathrm{t}>1.96)$ and $\mathrm{p}<0.001(\mathrm{t}>2.58)$. Here, we discuss about the result of our proposed extended UTAUT2 model by findings the consistency and inconsistency of the 
previous study on mobile banking adoption on the UTAUT2 model. From Table8,we found $\mathrm{BI} \rightarrow \mathrm{UB}(\mathrm{t}=4.8398, \beta=0.5012), \mathrm{FC} \rightarrow \mathrm{UB}(\mathrm{t}=2.6256, \beta=0.2806)$ and $\mathrm{SI} \rightarrow \mathrm{BI}(\mathrm{t}=2.1819, \beta=0.2579)$ indicating $\mathrm{H} 3, \mathrm{H} 5, \mathrm{H} 10$ were supported and the rest of the relationship found insignificant.It means that $\mathrm{H} 1, \mathrm{H} 2, \mathrm{H} 4, \mathrm{H} 6, \mathrm{H} 7, \mathrm{H} 8, \mathrm{H} 9$, were not supported by this study. The performance expectancy result is consistent with the research [35, 41, 59].This study also supported by[95] since performance expectancy and effort expectancy is similar with perceived usefulness and perceived ease of use[11]. Effort expectancy is supported by our result, but not supported by other prior research[29, 35, 96].Social influence was not supported by [35, 96]but our findings is supportedby other findings[5]. Facilitating condition has a positive influence on usage behavior But no influence in behavioral intention to adopt $\mathrm{m}$-banking services. This result is consistent with the $[29,35]$ but this result contradicts with many prior findings[28, 41, 59]. Price value has no influence on behavioral intention revealed by our findings is supported by with some earlier research [35, 61, 97] but contradicts others[12, 58]. The hedonic motivation is similar to the findings of $[12,35,98]$. Prior research found that habit to use m-banking is considered as an important predictor [99] and the relationship between habit and behavioral intention found prior findings $[35,40,41]$ though this research revealed no significant relationship. And in case of website quality WQ $\rightarrow$ UB (-0.1042) is not consistent with results of several studies, all of which reported that website quality affects behavioural intention, usage behaviour, and user satisfaction in theirdecision to adopt mobile banking services adoption [20,69, 71, 73, 76] but it has contradict by[100].Therefore, researchers finds that the Bangladeshi people are concern about other features of mobile banking services than the website quality while they are using m-banking services. Because mobile banking services adoption mainly depends upon the infrastructure of the financial firms, service provided by the organization, telecommunication facilities $(3 \mathrm{G}, 4 \mathrm{G})$ provided by the operators. They show their willingness to adopt more m-banking services.

\section{Conclusion}

The present study was designed to determine the effect of ten factors for acceptance of mobile banking service by the consumer and to investigate the relationship of website quality on mbanking service usage behavior in Bangladesh.In this paper,authors was used web site quality as a additional factor with the UTAUT2 model for justifying the consumer usage behavior of mbanking serveices.The study results supported three factors in the proposed research model.Authorsof the found that social influences positively influence on behavior intention, on the other hand usages behavior positively influenced by facilitating condition and behavior intention.It is also shown that to adopt mobile banking service website quality is not an important predictor factor for $\mathrm{m}$ - banking consumer. But overall, people of the mobile banking users become equally financially benefitted as like e-commerce users in Bangladesh[101]. One of the major limitation of this paper is a small sample size.Furthermore the original model has some moderators, but our proposed model we are excluding those as well as we do not take cross cultural approach which may limit the generalizability of our study. Further research should investigate those moderators factors this model with large sample size and include other additional external variable such as perceived risk, trust or brand equity,which can explain behavioral intention and usage behavior better than our existing research.

\section{REFERENCES}

[1] J. Sripalawat, M. Thongmak, and A. Ngramyarn, "M-banking in metropolitan Bangkok and a comparison with other countries," Journal of computer information systems, vol. 51, pp. 67-76, 2011.

[2] E. Scornavacca and H. Hoehle, "Mobile banking in Germany: a strategic perspective," International Journal of Electronic Finance, vol. 1, pp. 304-320, 2006.

[3] H. Karjaluoto, H. E. Riquelme, and R. E. Rios, "The moderating effect of gender in the adoption of mobile banking," International Journal of Bank Marketing, vol. 28, pp. 328-341, 2010. 
[4] L. Zhang, J. Zhu, and Q. Liu, "A meta-analysis of mobile commerce adoption and the moderating effect of culture," Computers in Human Behavior, vol. 28, pp. 1902-1911, 2012.

[5] C. Martins, T. Oliveira, and A. Popovič, "Understanding the Internet banking adoption: A unified theory of acceptance and use of technology and perceived risk application," International Journal of Information Management, vol. 34, pp. 1-13, 2014.

[6] F. Bass, "A New Product Growth Model for Consumer Durables. Management Sciences," Institute for Operations Research and the Management Sciences. Evanston, XV (5), 1969.

[7] J. Fenn and M. Raskino, Mastering the hype cycle: how to choose the right innovation at the right time: Harvard Business Press, 2008.

[8] F. D. Davis, "Perceived usefulness, perceived ease of use, and user acceptance of information technology," MIS quarterly, pp. 319-340, 1989.

[9] F. D. Davis, R. P. Bagozzi, and P. R. Warshaw, "User acceptance of computer technology: a comparison of two theoretical models," Management science, vol. 35, pp. 982-1003, 1989.

[10] E. Rogers, "Diffusion of Innovations (4th Eds.) ACM The Free Press (Sept. 2001)," New York, pp. $15-23,1995$.

[11] V. Venkatesh, M. G. Morris, G. B. Davis, and F. D. Davis, "User acceptance of information technology: Toward a unified view," MIS quarterly, pp. 425-478, 2003.

[12] V. Venkatesh, J. Y. Thong, and X. Xu, "Consumer acceptance and use of information technology: extending the unified theory of acceptance and use of technology," MIS quarterly, vol. 36, pp. 157$178,2012$.

[13] M. Pagani, "Determinants of adoption of third generation mobile multimedia services," Journal of interactive marketing, vol. 18, pp. 46-59, 2004.

[14] F. Calisir and C. A. Gumussoy, "Internet banking versus other banking channels: Young consumers' view," International Journal of Information Management, vol. 28, pp. 215-221, 2008.

[15] P. Gerrard and J. Barton Cunningham, "The diffusion of internet banking among Singapore consumers," International Journal of Bank Marketing, vol. 21, pp. 16-28, 2003.

[16] M. S. T. Md. Golzare Nabi, Prajna Paramita Saha, Rama Rani Sutradhar, Ayesha-E-Fahmida, and CGAP officials namely Gregory Chen and Shweta Banerjee. (2012, 01.03.2016). Mobile Financial Services in Bangladesh:An Overview of Market Development ,http://www.amtob.org.bd/resource/Mobile\%20Financial\%20Services\%20in\%20Bangladesh.pdf.

[17] Mobile Financial Services (MFS) comparative summary statement of November, 2015 and December, 2015. Available: https://www.bb.org.bd/fnansys/paymentsys/mfsdata.php

[18] B. Ensor, T. Montez, and P. Wannemacher, "The state of mobile banking 2012," Forrester Research, USA, 2012.

[19] A. M. Aladwani and P. C. Palvia, "Developing and validating an instrument for measuring userperceived web quality," Information \& management, vol. 39, pp. 467-476, 2002.

[20] W. H. Delone and E. R. McLean, "The DeLone and McLean model of information systems success: a ten-year update," Journal of management information systems, vol. 19, pp. 9-30, 2003.

[21] D. L. Hoffman, T. P. Novak, and M. Peralta, "Building consumer trust online," Communications of the ACM, vol. 42, pp. 80-85, 1999.

[22] G. L. Urban, C. Amyx, and A. Lorenzon, "Online trust: state of the art, new frontiers, and research potential," Journal of Interactive Marketing, vol. 23, pp. 179-190, 2009.

[23] F. D. Davis, R. P. Bagozzi, and P. R. Warshaw, "Extrinsic and intrinsic motivation to use computers in the workplace1," Journal of applied social psychology, vol. 22, pp. 1111-1132, 1992.

[24] R. L. Thompson, C. A. Higgins, and J. M. Howell, "Personal computing: Toward a conceptual model of utilization," MIS quarterly, pp. 125-143, 1991.

[25] S. Taylor and P. Todd, "Assessing IT usage: The role of prior experience," MIS quarterly, pp. 561570, 1995.

[26] A. Bandura, Social foundations of thought and action: A social cognitive theory: Prentice-Hall, Inc, 1986.

[27] A. Negahban and C.-H. Chung, "Discovering determinants of users perception of mobile device functionality fit," Computers in Human Behavior, vol. 35, pp. 75-84, 2014.

[28] C.-S. Yu, "Factors affecting individuals to adopt mobile banking: Empirical evidence from the UTAUT model," Journal of Electronic Commerce Research, vol. 13, pp. 104-121, 2012.

[29] I. Im, S. Hong, and M. S. Kang, "An international comparison of technology adoption: Testing the UTAUT model," Information \& Management, vol. 48, pp. 1-8, 2011.

[30] A. A. Shaikh and H. Karjaluoto, "Mobile banking adoption: A literature review," Telematics and Informatics, vol. 32, pp. 129-142, 2015. 
[31] Z. Liu, Q. Min, and S. Ji, "An empirical study on mobile banking adoption: The role of trust," in Electronic Commerce and Security, 2009. ISECS'09. Second International Symposium on, 2009, pp. 7-13.

[32] G. Ivatury and I. Mas, "The early experience with branchless banking," CGAP Focus Note, 2008.

[33] J. Donner and C. A. Tellez, "Mobile banking and economic development: Linking adoption, impact, and use," Asian journal of communication, vol. 18, pp. 318-332, 2008.

[34] Consumers and Mobile Financial Services 2015 Available: http://www.federalreserve.gov/econresdata/consumers-and-mobile-financial-services-report201503.pdf

[35] G. Baptista and T. Oliveira, "Understanding mobile banking: The unified theory of acceptance and use of technology combined with cultural moderators," Computers in Human Behavior, vol. 50, pp. 418-430, 2015.

[36] F. O. Bankole, O. O. Bankole, and I. Brown, "Mobile banking adoption in Nigeria," The Electronic Journal of Information Systems in Developing Countries, vol. 47(2), pp. 1-23, 2011.

[37] O. Bankole and E. Cloete, Mobile banking: A comparative study of South Africa and Nigeria: IEEE, 2011.

[38] K. Saeed, "Understanding the Adoption of Mobile Banking Services: An Empirical Assessment," in AMCIS, 2011.

[39] K. S. Tan, S. C. Chong, P. L. Loh, and B. Lin, "An evaluation of e-banking and m-banking adoption factors and preference in Malaysia: a case study," International Journal of Mobile Communications, vol. 8, pp. 507-527, 2010.

[40] X. Luo, H. Li, J. Zhang, and J. Shim, "Examining multi-dimensional trust and multi-faceted risk in initial acceptance of emerging technologies: An empirical study of mobile banking services," Decision support systems, vol. 49, pp. 222-234, 2010.

[41] T. Zhou, Y. Lu, and B. Wang, "Integrating TTF and UTAUT to explain mobile banking user adoption," Computers in Human Behavior, vol. 26, pp. 760-767, 2010.

[42] J.-C. Gu, S.-C. Lee, and Y.-H. Suh, "Determinants of behavioral intention to mobile banking," Expert Systems with Applications, vol. 36, pp. 11605-11616, 2009.

[43] G. Kim, B. Shin, and H. G. Lee, "Understanding dynamics between initial trust and usage intentions of mobile banking," Information Systems Journal, vol. 19, pp. 283-311, 2009.

[44] M. T. Ahad, L. E. Dyson, and V. Gay, "An empirical study of factors influencing the SME's intention to adopt m-banking in rural Bangladesh," Journal of Mobile Technologies, Knowledge \& Society, vol. 2012, pp. 1-16, 2012.

[45] M. N. A. Siddik, G. Sun, C. Yanjuan, and S. Kabiraj, "Financial Inclusion through Mobile Banking: A Case of Bangladesh," Journal of Applied Finance and Banking, vol. 4, p. 109, 2014.

[46] C. Dennis, B. Merrilees, C. Jayawardhena, and L. Tiu Wright, "An empirical investigation into eshopping excitement: antecedents and effects," European Journal of Marketing, vol. 43, pp. 11711187, 2009.

[47] H. H. Bauer, M. Hammerschmidt, and T. Falk, "Measuring the quality of e-banking portals," International journal of bank marketing, vol. 23, pp. 153-175, 2005.

[48] A. Floh and H. Treiblmaier, "What Keeps the E-Banking Customer Loyal? A Multigroup Analysis of the Moderating Role of Consumer Characteristics on E-Loyalty in the Financial Service Industry," A Multigroup Analysis of the Moderating Role of Consumer Characteristics on E-Loyalty in the Financial Service Industry.(March 26, 2006), 2006.

[49] L. C. Schaupp, W. Fan, and F. Belanger, "Determining success for different website goals," in System Sciences, 2006. HICSS'06. Proceedings of the 39th Annual Hawaii International Conference on, 2006, pp. 107b-107b.

[50] W. Z. Li and A. Y. Jiao, "The impact of website and offline equality on relationship quality: an empirical Study on e-retailing," in Wireless Communications, Networking and Mobile Computing, 2008. WiCOM'08. 4th International Conference on, 2008, pp. 1-5.

[51] W. B. Dodds, K. B. Monroe, and D. Grewal, "Effects of price, brand, and store information on buyers' product evaluations," Journal of marketing research, pp. 307-319, 1991.

[52] M. Limayem, S. G. Hirt, and C. M. Cheung, "How habit limits the predictive power of intention: the case of information systems continuance," Mis Quarterly, pp. 705-737, 2007.

[53] Y. Lee and K. A. Kozar, "Investigating the effect of website quality on e-business success: An analytic hierarchy process (AHP) approach," Decision support systems, vol. 42, pp. 1383-1401, 2006.

[54] S. Taylor and P. A. Todd, "Understanding information technology usage: A test of competing models," Information systems research, vol. 6, pp. 144-176, 1995. 
[55] D. R. Compeau and C. A. Higgins, "Computer self-efficacy: Development of a measure and initial test," MIS quarterly, pp. 189-211, 1995.

[56] A. S. Yang, "Exploring adoption difficulties in mobile banking services," Canadian Journal of Administrative Sciences/Revue Canadienne des Sciences de l'Administration, vol. 26, pp. 136-149, 2009.

[57] Y.-F. Kuo and S.-N. Yen, "Towards an understanding of the behavioral intention to use 3G mobile value-added services," Computers in Human Behavior, vol. 25, pp. 103-110, 2009.

[58] P. Luarn and H.-H. Lin, "Toward an understanding of the behavioral intention to use mobile banking," Computers in human behavior, vol. 21, pp. 873-891, 2005.

[59] T. Oliveira, M. Faria, M. A. Thomas, and A. Popovič, "Extending the understanding of mobile banking adoption: When UTAUT meets TTF and ITM," International Journal of Information Management, vol. 34, pp. 689-703, 2014.

[60] Y. S. Wang, H. H. Lin, and P. Luarn, "Predicting consumer intention to use mobile service," Information systems journal, vol. 16, pp. 157-179, 2006.

[61] H. Karjaluoto, N. Koenig-Lewis, A. Palmer, and A. Moll, "Predicting young consumers' take up of mobile banking services," International Journal of Bank Marketing, vol. 28, pp. 410-432, 2010.

[62] H.-F. Lin, "An empirical investigation of mobile banking adoption: The effect of innovation attributes and knowledge-based trust," International journal of information management, vol. 31, pp. 252-260, 2011.

[63] H. Van der Heijden, "User acceptance of hedonic information systems," MIS quarterly, pp. 695-704, 2004.

[64] J. Y. Thong, S.-J. Hong, and K. Y. Tam, "The effects of post-adoption beliefs on the expectationconfirmation model for information technology continuance," International Journal of HumanComputer Studies, vol. 64, pp. 799-810, 2006.

[65] S. S. Kim and N. K. Malhotra, "A longitudinal model of continued IS use: An integrative view of four mechanisms underlying postadoption phenomena," Management science, vol. 51, pp. 741-755, 2005.

[66] S. S. Kim, N. K. Malhotra, and S. Narasimhan, "Research note-two competing perspectives on automatic use: A theoretical and empirical comparison," Information Systems Research, vol. 16, pp. 418-432, 2005.

[67] I. Ajzen, "Residual effects of past on later behavior: Habituation and reasoned action perspectives," Personality and social psychology review, vol. 6, pp. 107-122, 2002.

[68] C. Dennis, B. Merrilees, C. Dennis, B. Merrilees, C. Jayawardhena, and L. Tiu Wright, "E-consumer behaviour," European Journal of Marketing, vol. 43, pp. 1121-1139, 2009.

[69] T. Ahn, S. Ryu, and I. Han, "The impact of Web quality and playfulness on user acceptance of online retailing," Information \& Management, vol. 44, pp. 263-275, 2007.

[70] J. E. Collier and C. C. Bienstock, "Model misspecification: contrasting formative and reflective indicators for a model of e-service quality," Journal of Marketing Theory and Practice, vol. 17, pp. 283-293, 2009.

[71] R. R. Nelson, P. A. Todd, and B. H. Wixom, "Antecedents of information and system quality: an empirical examination within the context of data warehousing," Journal of management information systems, vol. 21, pp. 199-235, 2005.

[72] A. Parasuraman, V. A. Zeithaml, and A. Malhotra, "ES-QUAL a multiple-item scale for assessing electronic service quality," Journal of service research, vol. 7, pp. 213-233, 2005.

[73] B. H. Wixom and P. A. Todd, "A theoretical integration of user satisfaction and technology acceptance," Information systems research, vol. 16, pp. 85-102, 2005.

[74] K. I. Al Qeisi and G. M. Al-Abdallah, "Website Design and Usage Behaviour: An Application of the UTAUT Model for Internet Banking in UK," International Journal of Marketing Studies, vol. 6, p. p75, 2014.

[75] A. M. Aladwani, "An empirical test of the link between web site quality and forward enterprise integration with web consumers," Business Process Management Journal, vol. 12, pp. 178-190, 2006.

[76] M. Alshehri, S. Drew, T. Alhussain, and R. Alghamdi, "The Effects of Website Quality on Adoption of E-Government Service: AnEmpirical Study Applying UTAUT Model Using SEM," in Australasian Conference On Information Systems 2012.

[77] U. Sekaran, Research methods for business: A skill building approach: John Wiley \& Sons, 2006.

[78] D. Straub, M.-C. Boudreau, and D. Gefen, "Validation guidelines for IS positivist research," The Communications of the Association for Information Systems, vol. 13, p. 63, 2004. 
[79] U. C. Eze, J. K. Manyeki, L. H. Yaw, and L. C. Har, "Factors affecting internet banking adoption among young adults: Evidence from Malaysia," in International Conference on Social Science and Humanity, 2011, pp. 377-381.

[80] W. W. Chin and P. R. Newsted, "Structural equation modeling analysis with small samples using partial least squares," Statistical strategies for small sample research, vol. 2, pp. 307-342, 1999.

[81] G. A. Marcoulides and C. Saunders, "Editor's comments: PLS: a silver bullet?," MIS quarterly, pp. iii-ix, 2006.

[82] W. W. Chin, "The partial least squares approach to structural equation modeling," Modern methods for business research, vol. 295, pp. 295-336, 1998.

[83] D. Barclay, C. Higgins, and R. Thompson, "The partial least squares (PLS) approach to causal modeling: Personal computer adoption and use as an illustration," Technology studies, vol. 2, pp. 285309, 1995.

[84] C. M. Ringle, S. Wende, and S. Will, "SmartPLS 2.0 (M3) Beta, Hamburg 2005," ed: OpenURL, 2005.

[85] H. Karjaluoto, "Selection criteria for a mode of bill payment: empirical investigation among Finnish bank customers," International Journal of Retail \& Distribution Management, vol. 30, pp. 331-339, 2002.

[86] R. Burke, "Hybrid recommender systems: Survey and experiments," User modeling and user-adapted interaction, vol. 12, pp. 331-370, 2002.

[87] V. S. Lai and H. Li, "Technology acceptance model for internet banking: an invariance analysis," Information \& management, vol. 42, pp. 373-386, 2005.

[88] W. M. Lassar, C. Manolis, and S. S. Lassar, "The relationship between consumer innovativeness, personal characteristics, and online banking adoption," International Journal of Bank Marketing, vol. 23, pp. 176-199, 2005.

[89] M. Sathye, "Adoption of Internet banking by Australian consumers: an empirical investigation," International Journal of bank marketing, vol. 17, pp. 324-334, 1999.

[90] J. Henseler, C. M. Ringle, and R. R. Sinkovics, "The use of partial least squares path modeling in international marketing," Advances in International Marketing (AIM), vol. 20, pp. 277-320, 2009.

[91] J. F. Hair Jr, G. T. M. Hult, C. Ringle, and M. Sarstedt, A primer on partial least squares structural equation modeling (PLS-SEM): Sage Publications, 2013.

[92] J. Hair, R. Anderson, L. Tatham, and W. Black, "Multivariate data analysis with regarding," Multivariate data analysis with regarding, 1992.

[93] B. Efron and R. J. Tibshirani, An introduction to the bootstrap: CRC press, 1994.

[94] J. F. Hair Jr, Hult, G Tomas M Ringle, Christian and Sarstedt, Marko, "A primer on partial least squares structural equation modeling (PLS-SEM)," ed: SAGE Publications, Inc., 2014, pp. 73-94

[95] A. AlSoufi and H. Ali, "Customers perception of mbanking adoption in Kingdom of Bahrain: an empirical assessment of an extended tam model," International Journal of Managing Information Technology (IJMIT), vol. 6, pp. 1-13, 2014.

[96] F. O. Bankole, O. O. Bankole, and I. Brown, "Mobile banking adoption in Nigeria," The Electronic Journal of Information Systems in Developing Countries, vol. 47, 2011.

[97] S. Yang, Y. Lu, S. Gupta, Y. Cao, and R. Zhang, "Mobile payment services adoption across time: An empirical study of the effects of behavioral beliefs, social influences, and personal traits," Computers in Human Behavior, vol. 28, pp. 129-142, 2012.

[98] A. Raman and Y. Don, "Preservice teachers' acceptance of Learning Management Software: An application of the UTAUT2 model," International Education Studies, vol. 6, p. p157, 2013.

[99] C. Liao, P. Palvia, and H.-N. Lin, "The roles of habit and web site quality in e-commerce," International Journal of Information Management, vol. 26, pp. 469-483, 2006.

[100]K. Al Qeisi and G. Al-Abdallah, "Internet banking adoption in Jordan: A behavioral approach," International Journal of Marketing Studies, vol. 5, p. 84, 2013.

[101]M. R. Hoque, M. A. Ali, and M. A. Mahfuz, "An Empirical Investigation on the Adoption of ECommerce in Bangladesh," Asia Pacific Journal of Information Systems, vol. 25, pp. 1-24, 2015. 


\section{Authors}

\section{Mohammad Abdullah Mahfuz}

Mohammad Abdullah Mahfuz is an assistant professor at Jagannath University of Marketing Department in Bangladesh. He is a $\mathrm{PhD}$ research fellow at School of Management, Wuhan University of Technology, Wuhan, Hubei, China. He received MBA and BBA degree from University of Dhaka, Bangladesh. Now He is working on Mobile banking adoption. His current research interests focus mainly on IT/IS adoption strategy, e-commerce, internet banking, m-banking, mobile tourism, Egovernment, M-government. He is a member of AIS and IEEE. Mr. Mahfuz has published a number of articles in different conference and peer reviewed academic journals.

\section{Liza Khanam}

Liza Khanam is an assistant professor of the Department of Management Studies, Jagannath University, Bangladesh. She is a $\mathrm{PhD}$ Research fellow at School of Management, Wuhan University of Technology, Wuhan, and P.R.Hubei, China. She received BBA and MBA degree from Dhaka University, Bangladesh. Now she is working research topic on Knowledge Management System adoption.Her current research interests include mainly KMS, IT/IS adoption strategy, E-government, Mgovernment, Green HRM. Miss. Khanam has published a number of articles in peerreviewed academic journals.

\section{Wang Hu}

Wang $\mathrm{Hu}$ is a professor, dean of Department of Information System and Information. Management at Wuhan University of Technology, Hubei, China. He studied in the University of Southern Queensland, Australia as a visiting scholar. His research area is an information system, e-commerce, e-business. He is also supervising both Chinese and international students at Masters and $\mathrm{PhD}$ level of Wuhan University of Technology.
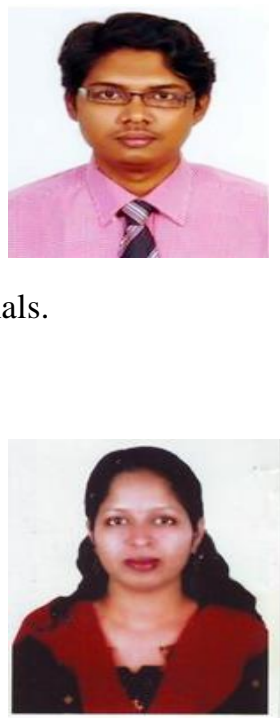
s. 